\title{
DA'WAH AS AN ALTERNATIVE APPROACH IN COVID-19 HEALTH PROTOCOL CAMPAIGN
}

\author{
Mochammad Irfan Achfandhy ${ }^{1 *}$ \\ State Islamic Institute of Metro, Lampung, Indonesia, e-mail:mochirfan@gmail.com \\ *Corresponding Author
}

\begin{tabular}{|c|c|c|}
\hline \multicolumn{3}{|c|}{ (c) ${ }_{\mathrm{EY}}^{(\mathrm{i})} \mathrm{SA}_{\mathrm{SA}}$} \\
\hline $\begin{array}{l}\text { (C2021 by the authors. Submitted for } \\
\text { Attribution-ShareAlike } 4.0 \text { Int } \\
\text { do) } 1\end{array}$ & $\begin{array}{l}\text { open access publication under } \mathrm{t} \\
\text { al License-(CC-BY-SA) (https:// } \\
\mathrm{t} / / / \mathrm{dx} \text {.doi.org/10.30983/islam red }\end{array}$ & $\begin{array}{l}\text { nd conditions of the Creative Commons } \\
\text { mmons.org/licenses/by-sa/4.0/) } \\
797\end{array}$ \\
\hline Submission: 20 September 2021 & Revised: 13 December 2021 & Published: 31 December 2021 \\
\hline
\end{tabular}

\section{Abstract}

This research aims to elaborate the communication strategy of Islamic Religious Counselors because communication strategies are an important aspect in the process of effectively transferring messages to the audiences. Islamic Religious Counselors are civil servant preachers who carry the mandate from the government to campaign for the Covid-19 health protocols through the da'wah (Islamic communication/propagation) approach. Da'wah and health materials are two different materials that pose challenges for Islamic Religious Counselors, especially in the communication patterns used. The research method used qualitative approach and multi-track communication theory by Thomas Tufte and Paolo Mefalopulos. Data were collected through structured interviews with six informants of Islamic Religious Counselor in Kalasan District and nonparticipant observations on each of their da'wah activities. The results showed that the preaching activities include recitation, socialization, social service and building relationships carried out with a multi-track communication strategy through a combination of a dialogic and one-step flow communication. Da'wah through a multi-track communication strategy has an impact on the affective side of religious congregations including attitudes, knowledge and awareness. Actualization of Islamic Religious Counselor is a viable alternative approach of the government and community in dealing with the Covid-19 pandemic.

Keywords: Da’wah, Communication, Covid-19, Islamic religious counselor.

\begin{abstract}
Abstrak
Penyuluh Agama Islam adalah pendakwah aparatur sipil negara yang mengemban amanah dari pemerintah untuk dapat mengampanyekan protokol kesehatan Covid-19 melalui pendekatan dakwah. Materi dakwah dan kesehatan merupakan dua materi berbeda yang menimbulkan tantangan bagi Penyuluh Agama Islam khususnya dalam pola komunikasi yang digunakan. Penelitian ini bertujuan untuk mengelaborasi strategi komunikasi Penyuluh Agama Islam karena strategi komunikasi merupakan aspek penting dalam proses transfer pesan kepada khalayak secara efektif. Metode penelitian menggunakan pendekatan kualitatif dan menggunakan teori komunikasi multi-track dari Thomas Tufte dan Paolo Mefalopulos. Data dikumpulkan melalui wawancara terstruktur dengan informan berjumlah 6 orang Penyuluh Agama Islam di Kecamatan Kalasan dan observasi non-partisipan pada setiap kegiatan dakwah. Hasil penelitian menunjukkan bahwa aktivitas dakwah Penyulub Agama Islam meliputi pengajian, sosialisasi, bakti sosial dan membangun relasi dilakukan dengan strategi komunikasi multi-track melalui kombinasi pendekatan komunikasi dialogis dan pendekatan satu arah. Dakwah melalui strategi komunikasi multi-track berdampak pada sisi afektif jama'ah meliputi sikap, pengetahuan dan kesadaran. Aktualisasi Penyuluh Agama Islam memberikan sebuah kontribusi sebagai alternatif pendekatan pemerintah maupun komunitas dalam menangani bencana Covid-19.
\end{abstract}

Kata Kunci: Dakwah, Komunikasi, Covid-19, Penyuluh agama Islam.

\section{Background}

The Covid-19 is virus that attacks the even death. ${ }^{1}$ Various media reported on respiratory tract can cause health problems and preventive actions and actions taken by the

${ }^{1}$ Geraldine D. Anzaldo, 'Modular Distance Learning International Journal of Scientific Advances, 2.3 (2021), 66, in the New Normal Education amidst Covid-19', <https://doi.org/10.51542/ijscia.v2i3.6>. 
government, such as closing schools, ${ }^{2}$ eliminating community activities that cause crowds, and prohibiting travel abroad. ${ }^{3}$ However, to realize the policy, it is necessary to involve various communities and community alliances. One of the government's efforts is to involve the $d a^{\prime} i$ (religious preachers) in community religious activities. The $D a^{\prime} i$ is a communicator whose job is to provide education in matters of Islamic teachings. ${ }^{4}$ However, they are also required to participate in realizing government policies that tend to fall into the scope of public health. Thus, this inconsistency raises various problems for a da'i, especially in the da'wah (Islamic propagation) communication strategy used.

In the religious aspect, the efforts to overcome the Covid-19 pandemic by the Ministry of Islamic Religion have been included in the Circular letter of the Minister of Religion of the Republic of Indonesia No. SE. 1 Year $2020 .^{5}$ In addition, the Indonesian Ulama Council (MUI) in Circular No. 14 of 2020 states that the instructions for implementing a new pattern of habits ("New Normal") include procedures for the arrangement of worship, marriage, recitation, funeral ceremonies as well as bajj and umrah (the minor and lesser Pilgrimage to Mecca, respectively). ${ }^{6}$ All worship activities

2 D. Adi and D. Setiautami, 'Distributing Information through Infographic on Tempodotco to Build Understanding and Awareness about COVID-19 Virus Outbreak in Indonesia', IOP Conference Series: Earth and Environmental Science, $729.1 \quad$ (2021), 1-2, <https://doi.org/10.1088/1755-1315/729/1/012109>.

3 Amos Sukamto and S. Panca Parulian, 'Religious Community Responses to the Public Policy of the Indonesian Government Related to the Covid-19 Pandemic', Journal of Law, Religion and State, 8.2-3 (2021), 83, <https://doi.org/10.1163/22124810-2020006>.

4 Rizki Briandana and others, 'D'a'wah Communication and Social Media: The Interpretation of Millennials in Southeast Asia', International Journal of Economics and Business Administration, 8.1 (2020), 26, $<$ https://doi.org/10.35808/ijeba/543>.

5 Menteri Agama RI, Pandemi, Surat Edaran Panduan Penyelenggaraan Kegiatan Keagamaan di Masa, (2020), p. $1-5$.

6 'Fatwa Majelis Ulama Indonesia Nomor 14 Tahun 2020 Tentang Penyelenggaran Ibadah dalam Situasi must be carried out with the New Normal protocol including; social distancing, physical distancing, ${ }^{7}$ screening or checking temperature, using masks, spraying disinfectants, as well as isolation and quarantine obligations for arrivals from outside the area. ${ }^{8}$ This government regulation is expected to be a reference and guideline for all community worship activities. The hope is that community worship activities during the Covid-19 pandemic will continue can hold back the spread of the virus.?

The government's efforts through the Ministry of Religion involve various community alliances including religious leaders $\left(d a^{\prime}\right)$. The Ministry of Religion appointed an Islamic Religious Counselor (PAI) because he has followers (jama'ah) and has a responsibility to the community to find solutions. ${ }^{10}$ The involvement of PAI as a da'i in campaigning for the New Normal is a form of collaboration with government stakeholders. This statement is supported by Ahyani as Plt. the Head of the Regional Office of the Ministry of Islamic Religion in Central Java, who stated that the task of Religious Counselors is not only to inform and foster religious teachings but also to inform government programs related to new patterns of habits or the New Normal culture of Covid-19 to the public. ${ }^{11}$ Therefore, the PAI da'wah

Terjadi Wabah COVID-19 - Protokol | Covid19.Go.Id' <https://covid19.go.id/p/protokol/ fatwa-majelisulama-indonesia-nomor-14-tahun-2020-tentang-

penyelenggaran-ibadah-dalam-situasi-terjadi-wabah-covid$19>\{$ accessed 11 July 2021$\}$.

7 Leny Latifah and others, 'Stigma and Mental Health during COVID-19 New Normal Transition in Indonesia', Indian Journal of Forensic Medicine \& Toxicology, 15.4 (2021), 35.

${ }^{8}$ Leny Latifah and others.

9 'Kementerian Komunikasi dan Informatika' <https://www.kominfo.go.id/content/detail/29179/siar an-pers-no-106hmkominfo092020-tentang-perpanjangwfh-menkominfo-terapkan-4m-dan-tetap-produktif/0/ siaran_pers $>$ accessed 26 August 2021$\}$.

10 Masdar Hilmy and Khoirun Niam, Winning the Battle of Authorities: The Muslim Disputes Over the Covid-19 Pandemic Plague', Qudus International Journal of Islamic Studies (QIJIS, 8.2 (2020), 293-326.

11 Tegubkan Peran Penyulub, Hadapi New Normal di Tengah Pandemi Covid-19 <https://jateng.kemenag.go.id/ 
required to be more active and creative in providing New Normal education to the community.

One of the Islamic Religious Counselors (PAI) who realized the New Normal education program is the Islamic Religious Counselor (PAI) of the Kalasan District, Sleman Regency. PAI of the Kalasan District contributed to the New Normal campaign under the instructions of the Ministry of Religion of the Sleman Regency. This was in response to the number of positive Covid-19 victims in the community which was high. Reporting from the Sleman Regent's circular letter, it was stated that there were instructions regarding the extension of the seven emergency response status for the Corona Virus Disease (Covid-19) disaster in the Sleman Regency. The circular letter provides evidence that the spread of Covid-19 in the Sleman Regency community was still high. The increasing number of victims shows that community discipline or compliance with the New Normal protocol is still very low. Reporting from an online news portal, Sleman Regency was recorded as the district with the most cases recorded on June 16, 2021, a total of 291 Covid19 cases in a day and a total of 18,426 in the Sleman Regency. ${ }^{12}$ Therefore, the role of PAI Kalasan is very urgent to provide preventive New Normal education.

However, on the other hand, the main task of a PAI is to preach. It is explained in the
Decree of Menkowasbang Pan No. 54/1999 that Religious Counselors are civil servants who are given full duties, responsibilities, authorities and rights by the authorities to carry out religious guidance and counseling as well as community development through religious discourse. ${ }^{13}$ PAI's task is to show that the actualization of da'wah is manifested in counseling and coaching the community in the context of religion. Da'wah is the process of delivering messages in the form of religious materials or Islamic teachings from a communicator to a communicant through public speaking in media such as radio, TV and YouTube. ${ }^{14}$ In general, da'wah can be defined as the effort to invite and guide people to a better direction or amar ma'ruf nabi munkar. ${ }^{15}$

Responding to this, the communication strategy in preaching is a very important element as an effort to adapted to the changing times. ${ }^{16}$ Communication strategies through an effective da'wah approach will have a significant impact on the community. ${ }^{17}$ The purpose of the PAI da'wah is expected to have an impact on social transformation and form a new pattern of habits (New Normal) in society. Based on the phenomenon of inconsistency of PAI practices above, the research focuses on examining how the communication strategy in PAI's da'wah activities in educating the New Normal policies to the local communities.

This analysis presents a multi-track communication model initiated by Thomas warta/berita/detail/ teguhkan-peran-penyuluh-hadapinew-normal-di-tengah-pandemi-covid-19> \{accessed 16 October 2020$\}$.

12 'Rekor! Kabupaten Sleman Catatkan Kasus Covid-19 Terbanyak dalam Sehari: Okezone News', Rabu $16 \quad$ Juni, 2021 <https://news.okezone.com/read/2021/06/16/510/242 6250/rekor-kabupaten-sleman-catatkan-kasus-covid-19terbanyak-dalam-sehari $>$ accessed 11 July 2021\}

13 Menteri Agama Republik Indonesia, Petunjuk Pelaksanaan Jabatan Fungsional Penyulub Agama dan Angka Kreditnya' (Jakarta, 1999) p. 3-7.

14 Muhammad Saufi Afliga, 'Da'wah Communication of Pondok Modern Darussalam Gontor Through Gontor TV's Youtube Channel', Sahafa Journal of
Islamic Communication, $1.1 \quad$ (2018), 2, http://dx.doi.org/10.21111/sjic.v1i1.2090.

15 Ahidul Asror Luluk Kholiqoh, 'Strategi Dakwah Ustadz Achmad Nasiruddin Arif dalam Mensyiarkan Ajaran Thoriqoh Naqsyabandiyah Kholidiyah Mujaddidiyah Kepada Generasi Muda di Kota Surabaya', Jurnal Ilmu Komunikasi Dan Dakwah Meyarsa, 2 (2021), 3-5.

16 Nasihatul Latifah and others, 'Character Education Values in Hanan Attaki's Millennial Da'wa', SSRN Electronic Journal, (2021), 1-5, <https://doi.org/ 10.2139/ssrn.3737471>.

${ }^{17}$ Umi Faizah and others, 'The Effectiveness of Interactive Audio Visual Learning Media in Speaking Competence for Dakwah', International Journal of Advanced Science and Technology, 29.6 Special Issue (2020), 1193-1202. 
Tufte and Paolo Mefalopulos. ${ }^{18}$ The multi-track communication model is one of the development communication models which is divided into two basic categories (two-way communication). ${ }^{19}$ The multi-track communication model with a monologic approach is adopted from the context of oneway linear flow, such as the diffusion of information on education, entertainment and political campaigns in conventional media. The second approach is dialogic (two-way dialogic process) which emphasizes the form of the process (process-based) rather than focusing on the final result (product-based), so that communication can help explore problems and produce adaptive solutions. ${ }^{20}$ The Multi-track communication paradigm is oriented towards development goals and empowering people's quality of life as well as those affected by Covid19.

This research used qualitative approach with a case study strategy. The case study strategy was chosen to see the multi-track communication strategy implemented in every PAI da'wah activity in the field and on social media. Data were collected through structured interviews and nonparticipant observations ${ }^{21}$ from every PAI activity in the Sleman District during the ongoing Covid-19 pandemic. There were six selected informants from all PAI members. The study was conducted in January to February 2021. In that period, the positive victims of Covid-19 in

18 Paolo Mefalopulos. Thomas Tufte, Participatory Communication A Practical Giude (Washington, D.C: The International Bank for Reconstruction and Development / The World Bank, 2009) p. 13-16.

19 Manon Koningstein and Shadi Azadegan, 'Participatory Video for Two-Way Communication in Research for Development', Action Research, 19.2 (2021), 36, <https://doi.org/10.1177/1476750318762032>.

${ }^{20}$ Lynn H. Turner Richard West, Pengantar Teori Komunikasi Analisis dan Aplikasi, ed. by Nina Setyaningsih, 3rd edn (Jakarta: PT Salamba Humanika, 2008) p. 10-15.

${ }^{21}$ Jhon W. Creswell, Research Design Qualitative, Quantitative and Mixed Metods Approaches, Cetakan VI (Yogyakarta: Pustaka Pelajar, 2009), p. 266.

${ }^{22}$ Gretchen B. Rossman and Sharon F. Rallis, $A n$ Introduction to Qualitative Research Learning in the Field (California: SAGE Publications, 2015), p. 236. the Kalasan district increased. Meanwhile, the data analysis technique used the pattern from Gretchen B. Rossman and Sharon F. Rallis by coding and classifying the data according to the characteristics $^{22}$ of the PAI da'wah practice. In addition, this analytical technique elaborates the data by involving the interpretation and reporting of the data in a comprehensive manner and can reduce the bias between the results of interviews and field observations.

From the previous literature review, the Covid-19 pandemic has given much impact on da'wah activities carried out by Islamic Religious Counselors (PAI). The results of Ibn Hajar's research show that the transformation of da'wah from classical da'wah patterns to modern patterns by utilizing social media is an urgent need. ${ }^{23}$ The WhatsApp and Facebook platforms are several alternatives that can easily reach the public during the Covid-19 pandemic. ${ }^{24}$ Sri Muchlis has shown that the implementation of PAI da'wab in broadcasting religious harmony can use several strategies and media selection. ${ }^{25}$ The strategy used is to create video lecture content and then distribute it to WhatsApp groups of PAIfostered groups. In contrast to the research above, this study focuses on the construction of communication strategies used by PAI Kalasan in the form of collaboration and harmonization of da'wah between religious and health aspects. The target of da'wah is focused on the weak (mustadh'afin) ${ }^{26}$ and people affected by Covid-19.

23 Ibnu Hajar, 'Strategi Dakwah Struktural Melalui Kebijakan Publik (Studi Terhadap Pelesatarian Terumbu Karang di Kabupaten Kepulauan Selayar)', (UIN Alauddin Makassar, 2018), p. 1-10.

24 Ika Nur Widiyanti, 'Transformasi Metode Dakwah Konvensional Komunitas Tauhid Kota Salatiga di Tengah Pandemi Covid-19', IMEJ: Islamic Management and Empowerment Journal, $3.1 \quad$ (2021), $\quad 79-96$ <https://doi.org/10.18326/imej.v3i1.79-96>.

25 Sri Muchlis, 'Strategi Komunikasi Dakwah Penyuluh Agama Islam dalam Menghadapi Pandemi Covid-19 di Kota Kisaran', Jurnal Ilmiah Komunikasi Communique, 3, (2020) https://doi.org/10.31289/ jikq.v3i1.36.

26 N L Khasanah, 'Metode Dakwah Transformatif Melalui Living Tilawatil Quran', An-Nida: Jurnal Komunikasi Islam, (2019), 2. 
The discourse of da'wab during the Covid-19 pandemic has been widely studied and researched. However, all references indicate that there is a need for emphasis on communication strategies as a response to the limitations of offline da'wah activities. The communication strategy must be clarified as a method of delivering messages effectively in da'wah, ${ }^{27}$ so that da'wah can have a significant impact and can be a reference for PAI's da'wah communication strategy for other regions. Therefore, da'wah can be used as an alternative to support government programs and can help break the chain of spread of Covid-19. ${ }^{28}$

\section{Islamic Religious Counselor's Da'wah Activities}

Terminologically, da'wah is defined as an attempt to invite. Meanwhile, in terms of da'wah, it can be interpreted as a persuasive act of a preacher to invite and influence others (mad'u) towards the good in accordance with the teachings of Islam. ${ }^{29}$ Basically, the da'wah process is a communication process. The elements of da'wah and communication include the process of delivering messages that are stimulus from a communicator to the communicant through a medium and are expected to have a changing effect on the communicator. Da'wah is based on the teachings of the Islamic religion delivered which aims to amar ma'rub nabi munkar ("enjoining the good, prohibiting the evil")..$^{30}$

In line with this, PAI Kalasan is one of the da'wah activists who are directly sheltered by government agencies. Thus, the existence of PAI Kalasan has legality from the government. PAI Kalasan has the duty and full responsibility for organizing counseling and guidance aimed at realizing national development in the discourse of religion. The PAI Kalasan Division is divided into two, namely Functionary Islamic Religious Extension (PAIF) and Non-Functionary or Honorary Religious Counselor (PAH). Members of the 2020 Functionary Islamic Religious Counselor (PAIF) in Kalasan District consist of two members. Meanwhile, the Honorary Islamic Religious Extension (PAH) or non-Functionary consists of eight people who have their own duties and focus. ${ }^{31}$

During the Covid-19 pandemic, the actualization of PAI Kalasan's da'wah activities underwent significant changes. One of the changes is aimed at the actualization of da'wah activities, which are now mostly held online. In addition, PAI Kalasan is required to continue to explore its da'wah activities that are oriented towards the goal of increasing community discipline in implementing the Covid-19 health protocols. The emergency of the epidemic became an urgent matter for PAI Kalasan's intervention in campaigning for the New Normal program. However, the difference of the two aspects of religion and health is one of the challenges for PAI Kalasan in preaching. The following are PAI Kalasan da'wah activities held during the Covid-19 pandemic:

\section{Islamic Teaching}

During the Covid-19 pandemic, most of the teaching activities were conducted online or via the internet. However, there are still some teachings that are conducted face-to-face (offline) such as in the Istiqomah 4 Study group which still holds face-to-face teachings every
27 Arianto Arianto, 'The Cohesiveness of Veiled Women's D'a'wah Communication Group', Ilmu Dakwah: Academic Journal for Homiletic Studies, 14.2 (2020), 341-62 <https://doi.org/10.15575/idajhs.v14i2.10674>.

${ }^{28}$ Ach. Baidowi, 'Da'wah Management of Islamic Religious Counselors in Pegantenan, Pamekasan during and Post Covid-19 Era', Muharrik: Jurnal Dakwah dan Sosial, $4.4 \quad$ (2021), $\quad 63-78$ <https://doi.org/10.37680/muharrik.v3i02.697>.
${ }^{29}$ Haidir Fitra Siagian and Fauziah Ahmad, 'The Position of D'a'wah Messages and Ethics in Malaysian and Indonesian Television Programs', Jurnal Komunikasi Malaysian Journal of Communication, 32.2 (2016), 749-69.

30 Andrew N. Weintraub, Music as a Medium for Communication, Unity, Education, and Dakwah, ed. by Routledge (United States of America: Taylor \& Francis eBooks, 2013), p. 185.

31 'KUA Kalasan' <https://www.simakkuakalasan.info/Galeri> \{accessed 18 March 2021\}. 
Friday night at 18.30 - 21.00 Western Indonesian Time. Most members of the Yasinan Istiqomah 4 study are local women. The congregation who attended was very enthusiastic with the number of around 40-50 people from the Kaliwaru Hamlet community. The Istiqomah 4 teaching program is packaged systematically which includes opening, tablilan, reciting Surah Yasin and prayer and closing with a lecture covering religious messages and material on new patterns of habits (New Normal). ${ }^{32}$

Furthermore, the PAI Kalasan recitation group is dedicated for children. This recitation group is packaged in the form of learning to read and write the Qur'an. It is located in the AlQuran Education Park (TPA) Masjid Al-Ikhlas, Kalasan District. Most students who take part are students in Kindergarten (TK) and Elementary School (SD) from around Segaran Hamlet. The lessons are held every Monday and Wednesday. In addition, learning to read and write the Qur'an is also followed by the adult age group. However, during the Covid-19 pandemic, learning was carried out online, namely by using the WhatsApp application. ${ }^{33}$ The recitation system applied is that each congregation performs muraja'ah or repetition of verses that have been studied and reports the results on Whatsapp Groups. At the end of the educational session, the New Normal program was conducted by PAI Kalasan to members of the Whatsapp Group.

\section{Public Socialization}

PAI Kalasan's da'wah is realized in the form of public outreach activities. One form of socialization activities for counseling and coaching PAI Kalasan is aimed at the "dogmatic" community. The "dogmatic" community is used to refer to those who do not believe that Covid19 is a deadly virus and has a detrimental impact

\footnotetext{
32 Umi Bariroh, (Islamic Religious Counselor) Interview \{Saturday, 20 February 2021 .

${ }^{33}$ Laeli Sholihah, Umi Bariroh, (Islamic Religious Counselor) Interview, \{Wednesday, 03 February 2021\}.
}

on health. They think that Covid-19 is just a form of conspiracy. Covid-19 was created by the elite to dominate the world in the trade, health and other sectors.

"There are some people in our community who don't care, don't know, and don't believe in the existence of Covid-19. This case is the most difficult. So we invite them to sit down for a discussion with good language. The material we convey is only nisbat or parables. So that PAI can understand and adapt effective communication. ${ }^{\text {“34 }}$

Socialization activities to the dogmatic communities are not carried out in a structured manner. Activities are carried out in a personal and private nature. This is to maintain the good name and security of the privacy of the dogmatic community itself. The form of counseling and guidance is done by chatting or chatting with each other and visiting their respective homes. The counseling and guidance process (socialization) is carried out periodically starting from October 2020 to February 2021. In Kalasan District, there are at least three or five people who have dogmatic and apathetic views about the Covid-19 pandemic. Despite that, there are still many such people who have not been registered by PAI Kalasan.

In addition, the socialization of PAI Kalasan was carried out by utilizing social media. PAI Kalasan created a video content containing the socialization of the Covid-19 health protocol. The message conveyed focused on the " $5 \mathrm{M}$ " campaign, namely wearing masks, washing hands, maintaining distance, avoiding crowds, limiting mobilization and interaction. The approach of the video narration is to persuasively invitate people to get used to a healthy lifestyle according to the Covid-19 protocol. ${ }^{35}$

The videos that have been produced are then distributed through the social media

34 Yatini, Umi Bariroh, (Islamic Religious Counselor) Interview, \{Monday, 03 January 2021\}.

35 'Naimatul Wardiah | Facebook' <https://web.facebook.com/naimatul.wardiah.3> \{accessed 18 March 2021\}. 
account of every Kalasan PAI on the WhatsApp and Facebook platforms. The advantage of these platforms is that they can reach the community at large and there are no specific restrictions. Diffusion of information of the 5M campaign could thereby reach all ages and all levels of society, especially the residents of the Kalasan District. In addition, social media Facebook and WhatsApp are the main choices because they can save costs and time. Thus, the socialization of new habit patterns (New Normal) through video content distributed through social media becomes a more effective and efficient alternative to da'wah.

\section{Social Community Service}

Social service is a form of mutual assistance based on a shared sense of humanity. The purpose of social service activities is to lighten the burden of those who face difficulty and increase the sense of kinship between each other. The social services carried out by PAI Kalasan can be classified into two types, namely philanthropic or long-term social service efforts and short-term charity. ${ }^{36}$

First, philanthropy is a social service that is sustainable and contributes to community empowerment. The idea designed by PAI Kalasan in the early period of the emergence of the Covid-19 pandemic was to set up a warung shodaqoh ("corner charity shop"). ${ }^{37}$ Activities are intended for the members of the congregation. The warung shodaqoh aims at helping members of the recitation congregation who are experiencing economic difficulties due to the impact of Covid19. Efforts to raise funds for the warung shodaqoh activity by PAI Kalasan and its fostered groups were allocated in the form of business capital. This aims to ensure that the business capital can be used to maintain the continuity of the entrepreneurship of the congregation during the Covid-19 pandemic. The philanthropic effort of providing business capital through the warung shodaqoh activity is oriented towards the goal of empowering UMKM (micro, small and medium enterprises).

Second, PAI Kalasan's charitable activity is to carry out social services in the form of distributing social assistance to refugees from the eruption of Mount Merapi. Mount Merapi, which has the alert status three, has had a tremendous impact on the community, not to mention the Covid-19 outbreak, whose case graph is still high. The contribution made is to provide primary assistance such as clothes, mats, blankets, and equipment for worship. In addition, PAI Kalasan continues to spread information about the New Normal policies as one of the main priorities. The manifestation of PAI Kalasan's contribution is to provide tools or equipment for the Covid-19 health protocols, which includes masks, hand-washing soap, face shields, and hand sanitizer. ${ }^{38}$

\section{Building Social Relation}

PAI Kalasan's New Normal campaign program recruited several agents as stakeholders or involved parties and stakeholders. The efforts in building social relations are made through the role of agents from various levels of society. One of the explicit actualizations of Kalasan PAI in building social relations is collaborating with government institutions. Leaders as holders of positions of power in a region are very influential in constructing change. PAI Kalasan's New Normal campaign efforts to build relationships with several power holders were carried out from the sub-district level to the neighborhood levels (RT/RW). ${ }^{39}$ Efforts to build relationships through sub-district and village government
${ }^{36}$ Hendy Mustiko Aji and others, 'Investigating the Determinants of Online Infaq Intention during the COVID-19 Pandemic: An Insight from Indonesia', Journal of Islamic Accounting and Business Research, 12.1 (2021), 1-3 <https://doi.org/10.1108/JIABR-05-2020-0136>.
37 Sukirno, (Islamic Religious Counselor) Interview, \{Monday, 10 January 2021\}.

38 Bakti Sosial Pengungsi Gunung Merapi, fleld Observation \{Monday, 24 January 2021 \}.

39 Sigit Murjaka, (Islamic Religious Counselor) Interview, \{Thursday, 18 January 2021\}. 
agents aim to determine the flow of data and information related to the residents of the Kalasan District. The data and information extracted include economic data, education, and especially religious activities.

In addition, data and information related to the control and handling the Covid-19 outbreak are also very important. Policies related to LargeScale Restrictions (PSBB), quarantine and isolation, social impact mitigation initiatives, and other community activity policies are the main things that must be socialized. ${ }^{40}$ In the religious sector, sub-district and village officials are tasked with creating social institutions as a preventive measure. Social infrastructure enacts guidelines to prevent conflict and tension in religious worship during the pandemic as in activities that cause crowds, namely wedding ceremonies, funeral ceremonies, traditional activities, even to the parameter policies of licensing the implementation of worship in mosques and prayer rooms. In addition to the religious sector, the involvement of government institutions in the work role of PAI Kalasan includes helping the economic condition of the community. The Amil and Zakat Agency of the Sleman Regency is one of the relation agents of PAI Kalasan. One of the efforts made is the contribution of necessities and social funds for communities affected by Covid-19.

Furthermore, PAI Kalasan cooperates with government agencies engaged in health. The intervention of the Kalasan Health Center together with the Kalasan PAI was to establish a Community-Based Sanitation Community (STBM). The STBM community is engaged in the field of public health. Several activities have been carried out such as the Mask Festival in January and the Direct Health Socialization or through the media of pamphlets, posters, and social media. ${ }^{41}$ Thus, social relations through government agencies are an indicator to realize community change. PAI Kalasan is claimed to be the vanguard of coordination and mediator from the community to the government so that the relationship between the government and the community can be mutually beneficial and complementary.

In addition, PAI Kalasan also builds social relations through non-government agencies. The contribution of non-government agency agents in the religious sector of the community is evidenced by the collaboration with one of the Directorate of Education and Development of Islam (DPPAI) in Islamic University of Indonesia (UII) in forming convert groups throughout the Kalasan District community. This institution is engaged in recruiting individuals from the Kalasan community who have recently converted to Islam. This form of collaboration is realized through educational efforts to strengthen faith and the practice of the Shari'a. For eight meetings in two months, education for converts was held at the KUA (Religious Affairs) District Office of Kalasan accompanied by the Kalasan PAI.

In the economic sector, PAI Kalasan cooperates with non-governmental institutions such as the Amil Zakat and Shodaqoh of Muhammadiyah Institute (LAZISMU) and the Zakat Empowerment Office (UPZ) in the Sleman Regency. The collaboration aims to contribute to easing the economic burden of the Kalasan District community. Some of the activities include micro/small business communities, people with disabilities, and converts to Islam. Some of them include Termination of Employment (PHK), decreased income or bankruptcy in micro businesses, people living with Covid-19 patients, and people who are vulnerable to Covid-19 transmission,

40 Catur Suratnoaji and Irwan Dwi Arianto, 'Public Opinion on Lockdown (PSBB) Policy in Overcoming COVID-19 Pandemic in Indonesia : Analysis
Based on Big Data Twitter, Asian Journal for Public Opinion Research, 8.3 (2020), 393-406.

${ }^{41}$ Khoirul Huda, (Islamic Religious Counselor) Interview, \{Monday, 21 Feburary 2021$\}.$ 
and the elderly. ${ }^{42}$ Gatherings and giving donations are methods of strengthening ukbuwah Islamiyah (Islamic solidarity) during the pandemic so that counseling and guidance can continue to run and the community's economy can be helped by the contribution of PAI Kalasan.

\section{The Construction of Da'wah Messages}

Message is one of the most important elements in the da'wah process. ${ }^{43}$ The elements of da'wah messages reflect an idea, and information conveyed to listeners in the form of verbal and non-verbal messages. The construction of the da'wah message determines the internalization parameters and changes to the intended object. Such is the case with the construction of PAI Kalasan da'wah message, which has special characteristics that are tailored to the expected goals. The first characteristic shows that the nature of the messages conveyed tends to be a combination of religious and health-oriented material which is indicated by the strengthening of faith and health or collaborative messages.

PAI Kalasan's collaborative message diffusion is conveyed with the characteristics of verbal and non-verbal messages, whereby PAI Kalasan assists in the internalization of religious and health values by exhorting its congregations to always comply with the Covid-19 health protocols. As is the case, the socialization of the health protocol occurs in a series of manidhoh (religious sermon) events at recitation activities. In addition, non-verbal collaborative messages are shown for students at the Al-Quran Education Park (TPA). That is, they are allowed to continue to recite the recitation only if they adhere to the Covid-19 health protocols.

In general, the construction of collaborative da'wah messages organized by PAI Kalasan is categorized into two: first, taking care of oneself (bifdzu nafs), namely personal safety from the threat of the Covid-19 outbreak being the first priority. The message is worth an appeal to always take care of yourself according to the Covid-19 health protocol by keeping your distance, not crowding, washing hands, wearing masks and doing quarantine for immigrants from areas other than Kalasan District. In addition, individuals are encouraged to always increase the body's immunity with a healthy lifestyle such as eating regularly, exercising and resting. Second, maintaining religion (kbifdu diin), which is remembering that the Covid-19 outbreak has spread tremendously, obligations as Muslims such as the obligation to pray, zakat, fast and other worship must still be carried out. Selfapproach to Allah SWT is an important priority for every individual.

Furthermore, the messages conveyed by PAI Kalasan tend to advocate or defend the weak (mustadh'afin) and communities affected by Covid-19. The message of participatory da'wah is shown in social service activities. Social service activities in the form of philanthropy and charity aim to help ease the burden on the poor (mustadh'afin). PAI Kalasan's social services are aimed at people affected by Covid-19 such as decreased income, layoffs (PHK), victims of positive Covid-19 patients, people who are vulnerable to the virus and even victims who die from Covid-19. On the other hand, PAI Kalasan also provided basic food assistance and Covid-19 health protocols (prokes) to communities affected by the eruption of Mount Merapi.

\section{The Implementation of Multi-Track Communication Strategy Da'wah}

The government's policy related to the new habit pattern (New Normal) is one example of government innovation to suppress the spread of Covid-19. ${ }^{44}$ The spread of innovation in the

Komunika: Jurnal Dakwah dan Komunikasi 15.1 (2021), 125, https://doi.org/10.24090/komunika.v15i1.4696.

44 Luca Bonacini, Giovanni Gallo, and Sergio Scicchitano, 'Working from Home and Income Inequality: Risks of a "New Normal" with COVID-19', Journal of 
form of the New Normal public policy is very dependent on the communication strategy that is determined. ${ }^{45}$ An increasingly effective communication strategy to the community can bring about social changes that are expected by the government as is the case with the da'wah communication strategy carried out by PAI Kalasan. The spread of innovation in the form of a New Normal public policy through a da'wah approach needs to explicitly determine the association of communication strategy selection.

Observational data from several activities of PAI Kalasan show that the first communication strategy implemented was a dialogic communication strategy (two-way dialogic process). Education and counseling of PAI Kalasan to dogmatic people who do not believe in the existence of Covid-19 is carried out with this dialogical communication strategy. The action taken is to discuss and invite to talk personally with two-way communication. In addition, the emphasis of language and the choice of diction used are always considered. The use and selection of language is done as a convergence effort in a dialogical communication process. The dialogical communication approach aims to create convergence, which is to create similarities in understanding and reduce the occurrence of misunderstandings or misunderstandings between PAI Kalasan and the dogmatic community. This is due to the understanding of anti-Covid-19 which is a form of ideology that is very difficult to reduce in order to switch to a new understanding or ideology.

In addition, the pattern of dialogic communication is also shown in activities to build social relations. PAI Kalasan collaborates with government and non-government institutions to create a new pattern of habits (New Normal) in the community. Cooperation with government and non-government institutions is a form of association to realize community development. The form of the dialogical approach is realized through a group discussion forum (FGD) or limited meeting. In the forum, PAI Kalasan provided an opportunity to exchange ideas and ideas through interactive dialogue. This is intended to create a mutual agreement between the two parties.

In line with the implementation of dialogic communication (two way dialogic process), in different forums, PAI Kalasan implemented a one-step flow communication strategy. One-way linear flow communication strategy is a communication strategy with onestage information delivery. Messages to mad'u or communicants are conveyed in one direction from the communicator by not giving room for feedback so that responses and rebuttals from mad'u cannot be conveyed to the communicator or preacher. In general, the one-step flow communication strategy uses media as a means of conveying messages such as newspapers, radio, television and posters.

Like the counseling conducted by PAI Kalasan to the children's age group at the AlQuran Education Park (TPA) Al-Ikhlas, PAI Kalasan provides counseling and guidance in learning the Koran. In addition, PAI Kalasan always educates students on new habit patterns (New Normal). Strictly speaking, PAI Kalasan gives instructions to the students of the $\mathrm{Al}$ Quran Education Park (TPA) and provides punishment for those who violate the Covid-19 protocol. . On the other hand, the students of the Al-Quran Education Park (TPA) were awarded for compliance in implementing the Covid-19 protocol in learning activities. This effort aims to increase enthusiasm and enthusiasm in reading the Koran. Thus the one way linear flow communication strategy carried out by PAI
Population Economics, $34.1 \quad$ (2021),

< https://doi.org/10.1007/s00148-020-00800-7>.

45 Ratri Candrasari and others, 'Learning

Communication Strategy at Colleges During the Covid-19
60 Pandemic and the New Normal Phase', Conference: International Conference on Social Science, Political Science, and Humanities, (2021), 18-23. 
Kalasan has a vision to continue to improve discipline and compliance with Covid-19 by providing punishment and reward.

This also confirms that mad'u or the object of PAI Kalasan is not only at the youth and adult levels. PAI Kalasan's da'wah also leads to the children's age with a one way linear flow communication strategy. The one-step flow communication strategy is an effective choice that is adapted to the conditions of the children's age group. One step flow communication shows instructive communication. In general, instructive is a communication approach that is carried out by commanding firmly and definitely. Generally, instructive communication patterns are strengthened by the enactment of binding regulations or laws.

The results of the analysis show that the implementation of the multi-track communication strategy is implemented in two stages, namely dialogic communication (two-way dialogic process) and one way communication (one-way linear flow). Implementation of multitrack communication strategy is shown in da'wab activities such as recitation, public outreach, social service and building social relations. Efforts to implement a multi-track communication strategy are supported by the construction of collaborative messages and advocacy in the form of defending and empowering the weak (mustadh'afin) affected by Covid-19. Thus, the problem of the inconsistency in the task of Kalasan PAI which must campaign for a new habit pattern (New Normal) does not become a very significant problem in the context of communication. PAI Kalasan's da'wah can associate and combine multi-track communication strategies by bringing two materials, religion and health, in a complementary way.

The multi-track communication strategy carried out by PAI Kalasan can provide a new idea in the field of da'wah. The purpose of the

${ }^{46}$ Kim S Martin, Health Communication Partnership: The New P-Process Steps in Strategic Communication, Johns multi-track communication strategy is to encourage a social change that is oriented towards the achievement of social welfare. The characteristics of a multi-track communication strategy are included in the context of development communication. Thus, multidisciplinary science and field practice can be reflected by PAI Kalasan. The concept of a multi-track strategy can be applied in da'wah activities which are a combination of cooperative and collective mutuality.

However, there are several preaching activities of PAI Kalasan that need further elaboration. The implementation of a multi-track communication strategy in promoting social change is still at the cybernetics stage. This stage focuses on the stages of the system and the patterns used in conveying the communicator's message. The multi-track strategy is designed only to promote change at the level of awareness, knowledge and attitude so that PAI Kalasan's efforts only have an impact on the affective side of the individual. The next recommendation for PAI Kalasan is to collaborate again the multitrack communication strategy with re-assistance in preaching. According to the P-Process communication planning strategy which was originally initiated by the Center for Communication Programs (CCP) of Johns Hopkins University, America, in health communication such as encouraging safer sexual behavior to prevent HIV transmission, increasing child survival, increasing contraceptives, preventing disease infectious or promoting environmental health including Covid-19 requires monitoring with re-assisting measures in the community. ${ }^{46}$

Da'wah with the aim of development cannot be done only on one occasion. There is a need for re-assistance efforts, namely efforts to monitor the progress of mad'u or PAI Kalasan assisted groups on a regular basis. This recommendation can be realized by direct action

Hopkins: Bloomberg School of Public Health Communication Partnership, 2003) p. 30-45. . 
that has an impact on the cognitive psychology side of the mad'u or the community. Soerjono Soekanto said that one of the supporting factors for social change was supervision and assistance. ${ }^{47}$ Re-assistance can be an indicator of the realization of social change in the form of increasing community compliance and discipline behavior towards the Covid-19 health protocol. This is in line with the government's goal of issuing a new habit pattern policy (New Normal) so that people remain productive in carrying out daily activities by always complying with the Covid-19 protocol. PAI Kalasan can contribute to campaigning for government policies through a da'wah approach so that it can run effectively and efficiently and can provide new scientific ideas about disaster mitigation da'wah.

\section{Conclusion}

Responding to the problem of inconsistency in the tasks of the Islamic Religious Counselor (PAI) Kalasan, several da'wah activities were reconstructed so that da'wah could educate the public which includes not only religious material but also new habit patterns (New Normal) during the Covid-19 pandemic. The contribution that can be made by PAI Kalasan is by organizing recitation activities, public outreach, social services and building relationships. All of the da'wah activities are carried out offline and online by utilizing social media Whatsapp and Facebook as alternative media. All Kalasan PAI da'wah activities have a collaborative message construction by including khifdun ill-fated and khifduddin messages as well as messages that are advocacy or defense to the weak (mustadh'afin) and communities affected by Covid-19 such as those who experience a decrease in income, work termination (PHK), victims of positive Covid-19 patients, people who are vulnerable to the virus and even victims who die from Covid-19. The activity and construction of da'wah message of PAI Kalasan is conveyed through a multi-track communication strategy, namely by collaborating dialogic communication or a two-way dialogic process and one-step flow communication. But on the other hand, the multi-track communication strategy is considered less effective in shaping social change in the form of increasing compliance behavior and community discipline for new patterns of habits (New Normal). Multi-track communication strategies can only have an impact on the affective side of mad'u. Thus, there is a need for re-assistance as a form of monitoring to realize community change from the affective and cognitive side. In line with that, PAI Kalasan's intervention in responding to the urgency of the Covid-19 pandemic disaster provided a new paradigm in da'wah studies. Da'wah activities can be used as an alternative government approach in disaster management efforts so that da'wah research of disaster mitigation needs to be explored more widely as a manifestation of multidisciplinary science.

\section{References \\ Books}

Creswell, Jhon W., Research Design Qualitative, Quantitative and Mixed Metods Approaches, Cetakan VI (Yogyakarta: Pustaka Pelajar, 2009)

Martin, Kim S, Health Communication Partnership: The New P-Process Steps in Strategic Communication, (Johns Hopkins: Bloomberg School of Public Health Communication Partnership, 2003)

Rallis, Gretchen B. Rossman and Sharon F., $A n$ Introduction to Qualitative Research Learning in the Field (California: SAGE Publications, 2015)

Richard West, Lynn H. Turner, Pengantar Teori Komunikasi Analisis dan Aplikasi, ed. by Nina Setyaningsih, 3rd edn (Jakarta: PT Salamba Humanika, 2008)

Soekanto, Soerjono, Sosiologi Suatu Pengantar 
(Depok: PT Raja Grafindo Persada, 2017)

Weintraub, Andrew N., Music as a Medium for Communication, Unity, Education, and Dakwah, ed. by Routledge (United States of America: Taylor \& Francis eBooks, 2013)

Thomas Tufte, Paolo Mefalopulos., Participatory Communication A Practical Giude (Washington, D.C: The International Bank for Reconstruction and Development/ The World Bank, 2009)

\section{Journals}

Adi, D., and D. Setiautami, 'Distributing Information through Infographic on Tempodotco to Build Understanding and Awareness about COVID-19 Virus Outbreak in Indonesia', IOP Conference Series: Earth and Environmental Science, 729.1 (2021), 1-2, https://doi.org/10.1088 /1755- 1315/729/1/012109

Afliga, Muhammad Saufi, Muhammad Saufi Afliga, 'Da'wah Communication of Pondok Modern Darussalam Gontor Through Gontor TV's Youtube Channel', Sabafa Journal of Islamic Communication, 1.1 (2018), 2, http://dx.doi.org/ 10.21111/sjic.v1i1.2090

Aji, Hendy Mustiko, Albari Albari, Muchsin Muthohar, Sumadi Sumadi, Murwanto Sigit, Istyakara Muslichah, and others, 'Investigating the Determinants of Online Infaq Intention during the COVID-19 Pandemic: An Insight from Indonesia', Journal of Islamic Accounting and Business Research, $12.1 \quad$ (2021), 1-20 $<$ https://doi.org/10.1108/JIABR-052020-0136>

Anzaldo, Geraldine D, 'Modular Distance Learning in the New Normal Education amidst Covid-19', International Journal of Scientific Advances, 2.3 (2021), 66 ,<https://doi.org/10.51542/ijscia.v2i3.6>

Arianto, Arianto, 'The Cohesiveness of Veiled Women's Da'wah Communication Group', Ilmu Dakwah: Academic Journal for Homiletic Studies, $\quad 14.2 \quad$ (2020), 341-62 <https://doi.org/10.15575/idajhs.v14i2.1 0674>

Baidowi, Ach., 'Da'wah Management of Islamic
Religious Counselors in Pegantenan, Pamekasan during and Post Covid-19 Era', Muharrik: Jurnal Dakwah dan Sosial, 4.Vol 4 No $01 \quad$ (2021), 63-78, $<$ https://doi.org/10.37680/muharrik.v3i0 $2.697>$

Bonacini, Luca, Giovanni Gallo, and Sergio Scicchitano, "Working from Home and Income Inequality: Risks of a "New Normal" with COVID-19', Journal of Population Economics, 34.1 (2021), 303-60 $<$ https://doi.org/10.1007/s00148-02000800-7>

Briandana, Rizki, Caturida Meiwanto Doktoralina, Shahir Akram Hassan, and Wan Norhaniza Wan Hasan, 'Da'wah Communication and Social Media: The Interpretation of Millennials in Southeast Asia', International Journal of Economics and Business Administration, 8.1 (2020), 26, <https://doi.org/10.35808/ijeba/543>

Candrasari, Ratri, Risna Dewi, Dini Rizki, Cut Rizka, Al Usrah, and Teuku Kemal Fasya, 'Learning Communication Strategy at Colleges During the Covid-19 Pandemic and the New Normal Phase', 495.ICoSPOLHUM 2020 (2021), 18-23

Faizah, Umi, Sarwiji Suwandi, Andayani, and Ani Rakhmawati, 'The Effectiveness of Interactive Audio Visual Learning Media in Speaking Competence for Dakwah', International Journal of Advanced Science and Technology, 29.6 Special Issue (2020), 11931202

Hajar, Ibnu, 'Strategi Dakwah Struktural Melalui Kebijakan Publik (Studi Terhadap Pelesatarian Terumbu Karang di Kabupaten Kepulauan Selayar)', (UIN Alauddin Makassar, 2018), p. 1-10

Hilmy, Masdar, and Khoirun Niam, "Winning the Battle of Authorities: The Muslim Disputes Over the Covid-19 Pandemic Plague', Qudus International Journal of Islamic Studies (QIJIS, 8.2 (2020), 293-326

Khasanah, N L, 'Metode Dakwah Transformatif Melalui Living Tilawatil Quran', An-Nida: Jurnal Komunikasi Islam, (2019), 2

Koningstein, Manon, and Shadi Azadegan, 
'Participatory Video for Two-Way Communication in Research for Development', Action Research Journal, 19.2 (2021), 36, <https://doi.org/10.1177/ 1476750318762032>

Latifah, Leny, Yusi Dwi Nurcahyani, Diah Yunitawati, Marizka Khairunnisa, and Cati Martiyana, 'Stigma and Mental Health during COVID-19 New Normal Transition in Indonesia', Indian Journal of Forensic Medicine \& Toxicology, 15.4 (2021), 35

Latifah, Nasihatul, Lilik Huriyah, Nuwailah R. Rufqoti, and Rohil Zilfa, 'Character Education Values in Hanan Attaki's Millennial Da'wah', SSRN Electronic Journal, (2021), $\quad 1-5, \quad<$ https://doi.org/ $10.2139 /$ ssrn. $3737471>$

Luluk Kholiqoh, Ahidul Asror, 'Strategi Dakwah Ustadz Achmad Nasiruddin Arif Dalam Mensyiarkan Ajaran Thoriqoh Naqsyabandiyah Kholidiyah Mujaddidiyah Kepada Generasi Muda Di Kota Surabaya', Jurnal Ilmu Komunikasi Dan Dakwah Meyarsa, 2 (2021), 3-5

Muchlis, Sri, 'Strategi Komunikasi Dakwah Penyuluh Agama Islam dalam Menghadapi Pandemi Covid-19 di Kota Kisaran', Jurnal Ilmiah Komunikasi Communique, 3, (2020) https://doi.org/ 10.31289/jikq.v3i1.36

Nicola, Maria, Zaid Alsafi, Catrin Sohrabi, Ahmed Kerwan, Ahmed Al-Jabir, Christos Iosifidis, and others, 'The Socio-Economic Implications of the Coronavirus Pandemic (COVID-19): A Review', International Journal of Surgery, 78 (2020), 185-93

Purwaningwulan, Melly Maulin, 'Da'wah Messages as the Spiritual Marketing Approach of Islamic Fashion E-Commerce at HIJUP, Komunika: Jurnal Dakwah dan Komunikasi $15.1 \quad$ (2021), 125, https://doi.org/10.24090/komunika.v15i1 .4696

Siagian, Haidir Fitra, and Fauziah Ahmad, 'The Position of Da'wah Messages and Ethics in Malaysian and Indonesian Television Programs', Jumal Komunikasi Malaysian Journal of Communication, 32.2 (2016), 749-69

Sukamto, Amos, and S. Panca Parulian,
'Religious Community Responses to the Public Policy of the Indonesian Government Related to the Covid-19 Pandemic', Journal of Law, Religion and State, 8.2-3 (2021), 83 <https://doi.org $/ 10.1163 / 22124810-2020006>$

Suratnoaji, Catur, and Irwan Dwi Arianto, 'Public Opinion on Lockdown (PSBB) Policy in Overcoming COVID-19 Pandemic in Indonesia: Analysis Based on Big Data Twitter', Asian Journal for Public Opinion Research, 8.3 (2020), 393-406

Thomas Tufte, Paolo Mefalopulos., Participatory Communication A Practical Giude (Washington, D.C: The International Bank for Reconstruction and Development / The World Bank, 2009)

Weintraub, Andrew N., Music as a Medium for Communication, Unity, Education, and Dakwah, ed. by Routledge (United States of America: Taylor \& Francis eBooks, 2013), p. 185

Widiyanti, Ika Nur, 'Transformasi Metode Dakwah Konvensional Komunitas Tauhid Kota Salatiga di Tengah Pandemi Covid19', IMEJ: Islamic Management and Empowerment Journal, 3.1 (2021), 79-96 $<$ https://doi.org/10.18326/imej.v3i1.79$96>$

\section{Online database}

'Fatwa Majelis Ulama Indonesia Nomor 14 Tahun 2020 Tentang Penyelenggaran Ibadah Dalam Situasi Terjadi Wabah COVID-19 - Protokol | Covid19.Go.Id' $<$ https://covid19.go.id/p/protokol/fatwa -majelis-ulama-indonesia-nomor-14-tahun2020-tentang-penyelenggaran-ibadahdalam-situasi-terjadi-wabah-covid-19> \{accessed 11 July 2021\}

Indonesia, Menteri Agama Republik, Petunjuk Pelaksanaan Jabatan Fungsional Penyuluh Agama dan Angka Kreditnya' (Jakarta, 1999) p. 3-7

'Kementerian Komunikasi dan Informatika' $<$ https://www.kominfo.go.id/content/det ail/29179/siaran-pers-no106hmkominfo092020-tentangperpanjang-wfh-menkominfo-terapkan- 
4m-dan-tetap-produktif/0/siaran_pers $>$ \{accessed 26 August 2021\}

'KUA Kalasan' <https://www.simakkuakalasan.info/Galeri> $>$ accessed 18 March 2021\}

'Naimatul Wardiah | Facebook' $<$ https://web.facebook.com/naimatul.war diah.3 $>$ \{accessed 18 March 2021\}

'Rekor! Kabupaten Sleman Catatkan Kasus Covid-19 Terbanyak dalam Sehari: Okezone News', Rabu 16 Juni, 2021 $<$ https://news.okezone.com/read/2021/0 6/16/510/2426250/rekor-kabupatensleman-catatkan-kasus-covid-19-terbanyakdalam-sehari> \{accessed 11 July 2021$\}$

RI, Menteri Agama, Pandemi, Surat Edaran Panduan Penyelenggaraan Kegiatan Keagamaan di Masa, (2020) p. 1-5

'Teguhkan Peran Penyuluh, Hadapi New Normal di Tengah Pandemi Covid-19' $<$ https://jateng.kemenag.go.id/warta/beri ta/detail/teguhkan-peran-penyuluhhadapi-new-normal-di-tengah-pandemicovid-19> \{accessed 16 October 2020$\}$

\section{Interview}

Bariroh, mi, (Islamic Religious Counselor) Interview, \{Saturday, 20 February 2021\}

Huda, Khoirul, (Islamic Religious Counselor) Interview, \{Monday, 21 Feburary 2021\}

Maswariah, mas, (Islamic Religious Counselor) Interview, \{Tuesday, 16 February 2021\}

Merapi, Bakti Sosial Pengungsi Gunung, Field Observation, \{Wednesday, 24 Januari 2021\}

Murjaka, Sigit, (Islamic Religious Counselor) Interview, \{Thursday, 18 January 2021\}

Sholihah, Laeli, (Islamic Religious Counselor) Interview, \{Wednesday, 03 February 2021\}

Sukirno, (Islamic Religious Counselor) Interview, \{Monday, 10 January 2021\}

Yatini, (Islamic Religious Counselor) Interview, \{Monday, 03 Januariy 2021 \} 